\title{
PLEKHG2-associated neurological disorder
}

\author{
Arushi Gahlot Saini, ${ }^{1}$ Naveen Sankhyan, ${ }^{1}$ Sameer Vyas ${ }^{2}$
}

${ }^{1}$ Pediatric Neurology Unit, Department of Pediatrics, Post Graduate Institute of Medical Education and Research, Chandigarh, India ${ }^{2}$ Department of Radiodiagnosis, Post Graduate Institute of Medical Education and Research, Chandigarh, India

\section{Correspondence to} Dr Arushi Gahlot Saini; doc.arushi@gmail.com

Accepted 12 July 2021
Check for updates

(C) BMJ Publishing Group Limited 2021. No commercial re-use. See rights and permissions. Published by BMJ.

To cite: Saini AG,
Sankhyan N, Vyas S. BMJ
Case Rep 2021;14:e244206.
doi:10.1136/bcr-2021-
244206

\section{DESCRIPTION}

An 11-year-old boy presented to us with intellectual disability and recurrent, unprovoked seizures since 3-4 months of age. His history revealed that the initial seizures were of generalised-onset tonic type. MRI of the brain at that time showed benign enlargement of the subarachnoid spaces (figure 1A-C). At 9 months of age, he developed flexor-type infantile spams. His seizures remitted temporarily by 12 months of age with antiepileptic drugs. A repeat MRI of the brain at this time showed resolution of subarachnoid space enlargement (figure 1D-F). At 8 years, he had recurrence of both generalised-onset tonic-clonic and focal-onset motor seizures. An electroencephalogram at this time showed generalised epileptiform discharges, and he was restarted on antiepileptic drugs. $\mathrm{He}$ was also noted to have poor scholastic performance and mild behavioural problems by this time. The perinatal period was uneventful. He was born to non-consanguineously married parents, and family history was not contributory.

Examination at 11 years of age showed microcephaly $(47.5 \mathrm{~cm},<-3 \mathrm{z})$, behavioural problems,

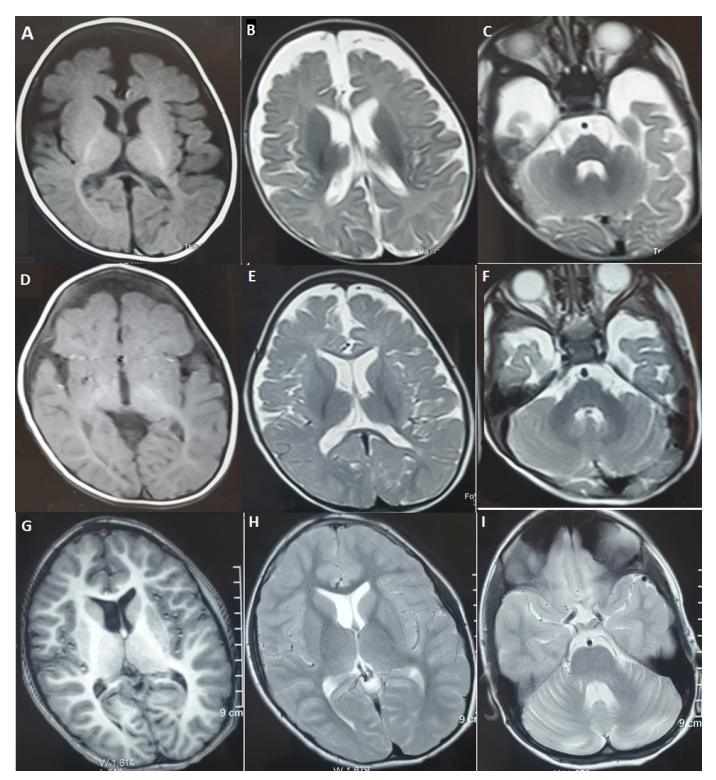

Figure $1(A-I)$ Axial sections of MRI of the brain at 3 months ( $A-C), 12$ months $(D-F)$ and 11 years of age $(\mathrm{G}-\mathrm{I})$ : at 3 months of age, there is benign enlargement of subarachnoid spaces and a small right-sided subdural effusion. At 12 months of age, these extra-axial spaces are mildly prominent with paucity of cerebral white matter. At 11 years of age, normal grey and white matter structures are appreciated; however, mild asymmetry of lateral ventricles is seen, which may be a normal variant. The section (I) at the level of the pons shows normal signal and mild cerebellar atrophy. stereotypic hand movements (hand twisting, flapping and wringing) and acral choreoathetoid movements. His intelligent quotient was 50. Blood acylcarnitine, amino acid and urinary organic acid profiles were normal. Electroencephalogram was normal. MRI of the brain at this age (11 years) showed mild cerebellar atrophy and reduced white matter (figure 1G-I). Genetic analysis showed a homozygous missense variant in exon 9 of the 'pleckstrin homology and RhoGEF domain containing G2' (PLEKHG2) gene (chr19:39908 657G $>$ T) that resulted in the amino acid substitution of valine for glycine at codon 332 (p.Gly332Val; ENST00000409794). The in silico predictions of the variant were probably damaging by PolyPhen-2 (HumDiv) and by Sorting Intolerant From Tolerant (SIFT), Likelihood Ratio Test (LRT) and MutationTaster2. Sanger sequencing confirmed the variation, and parents were carriers.

Homozygous variations in PLEKHG2 gene on chromosome $19 \mathrm{q} 13$ are associated with a severe neurodevelopment disorder characterised by leukodystrophy and acquired microcephaly with or without dystonia (LDAMD; OMIM \#616763). ${ }^{1}$ The original description of five children from two unrelated consanguineous Palestinian families showed an infantile-onset severe neurodevelopmental disorder, hypotonia, postnatal progressive microcephaly, nystagmus and tonic spasms (in one patient). ${ }^{1}$ In comparison, our patient had only some of the described classical features such as microcephaly and intellectual impairment. He additionally had autistic traits with motor and verbal stereotypies. Epilepsy, especially infantile-onset epileptic encephalopathy, seems a dominant finding in our case. PLEKHG2 gene has recently been implicated as one of the new candidate genes for genetic West syndrome and epilepsy. ${ }^{23}$

Leukodystrophy is a key descriptive term in the LDAMD disorder. Abnormal T2-weighted hyperintensities in the dorsal tegmental tracts in the pons, with atrophy of the white matter, have been interpreted as suggestive of leukodystrophy. ${ }^{1}$ The sequential neuroimaging findings in our patient at 3 months, 12 months and 11 years of age show an absence of progressive white matter changes. The improving clinical course, absence of spasticity, gait impairment or optic atrophy indicates a static phenotype rather than a degenerative brain disease as implied by the assigned term 'leukodystrophy. Hence, in view of very less number of patients described currently with PLEKHG2-associated disorders, a new term 'Microcephaly, Intellectual disability, Epilepsy and White-matter hypoplasia' (MIDEW) would probably better describe the most conspicuous findings of microcephaly, intellectual impairment and epilepsy, with a probable 
white matter involvement in a non-leukodystrophy pattern. The white matter involvement is probably related to a delayed developmental maturation, which later normalises with age in both volume and signal change. It needs to be seen in all the described cases whether the overall neurological illness and white matter involvement behave in a static or progressive manner. As both types of white matter involvements have been described in a small number of cases, more cases with PLEKHG2-associated

\section{Learning points}

- PLEKHG2-aasociated neurodevelopment disorder is associated with microcephaly, epilepsy and intellectual impairment, with or without dystonia.

- Our case shows the presence of white matter hypoplasia in place of leukodystrophy.

- The term MIDEW is suggested to describe the prominent neurological manifestations. disorders and longitudinal follow-up of affected children will help in the true characterisation of white matter affection in this recently described rare entity.

Contributors AGS was involved in drafting of manuscript and management of the case. NS was involved in review of the manuscript. SV was involved in review of radiological data.

Funding The authors have not declared a specific grant for this research from any funding agency in the public, commercial or not-for-profit sectors.

Competing interests None declared.

Patient consent for publication Parental/guardian consent obtained.

Provenance and peer review Not commissioned; externally peer reviewed.

\section{REFERENCES}

1 Edvardson S, Wang H, Dor T, et al. Microcephaly-dystonia due to mutated PLEKHG2 with impaired actin polymerization. Neurogenetics 2016;17:25-30.

2 Peng J, Wang Y, He F, et al. Novel West syndrome candidate genes in a Chinese cohort. CNS Neurosci Ther 2018;24:1196-206.

3 Wang J, Lin Z-J, Liu L, et al. Epilepsy-associated genes. Seizure 2017;44:11-20.

Copyright 2021 BMJ Publishing Group. All rights reserved. For permission to reuse any of this content visit

https://www.bmj.com/company/products-services/rights-and-licensing/permissions/

BMJ Case Report Fellows may re-use this article for personal use and teaching without any further permission.

Become a Fellow of BMJ Case Reports today and you can:

- Submit as many cases as you like

- Enjoy fast sympathetic peer review and rapid publication of accepted articles

- Access all the published articles

Re-use any of the published material for personal use and teaching without further permission

Customer Service

If you have any further queries about your subscription, please contact our customer services team on +44 (0) 2071111105 or via email at support@bmj.com.

Visit casereports.bmj.com for more articles like this and to become a Fellow 